\title{
Kajian Hadis: Iman, Islam dan Ihsan dalam Perspektif Pendidikan Agama Islam
}

\author{
Kuliyatun \\ Fakultas Tarbiyah \\ Universitas Muhammadiyah Metro Lampung \\ kuliyatun1971@gmail.com
}

\begin{abstract}
Learning methods and materials are an important part of the learning process. Rasulullah Saw's journey in every teaching mission cannot be separated from what he will teach, and how he teaches it to his Friends. Referring to the Prophet's education and teacher training pattern, in the Islamic perspective, teachers are a key position in shaping the true Muslim personality. Therefore, it is necessary to study the other side behind the success of Rasullah Saw in spreading Islam. This manuscript provides an analysis that learning material is scientific material that is determined in a learning process. While the method is a way of conveying material, both material that is real and ghoib. In glasses of methods and materials, from the hadith about the arrival of the angel Gabriel, Rasulullah Saw in delivering messages, using the method of conversation or question and answer, with Gabriel and his Friends. The material presented was about the concept of the pillars of religion, namely Islam, Faith, Ihsan and the End of Days.

Metode dan materi pembelajaran merupakan bagian penting dalam suatu proses pembelajaran. Perjalanan Rasulullah Saw dalam setiap misi mengajarnya tidak lepas dari apa yang akan diajarkan, dan bagaimana beliau mengajarkannya kepada para Sahabat. Merujuk pada pola pendidikan dan keguruan Rasulullah Saw, dalam perspektif Islam, guru menjadi posisi kunci dalam membentuk kepribadian muslim yang sejati. Oleh karena itu, perlunya mengkaji sisi lain dibalik suksesnya Rasulullah Saw menyebarkan Islam. Naskah ini memberikan analisis bahwa materi pembelajaran adalah bahan ilmu pengetahuan yang ditetapkan dalam suatu proses pembelajaran. Sedangkan metode merupakan cara dalam menyampaikan suatu materi, baik materi yang bersifat nyata maupun ghoib. Berkacamata dari metode dan materi dari hadis tentang kedatangan malaikat Jibril, Rasulullah Saw dalam menyampaikan pesan, menggunakan cara metode percakapan atau tanya jawab, dengan Jibril dan sahabatnya. Materi yang disampaikan seputar tentang konsep rukun agama, yaitu Islam, Iman, Ihsan dan Hari Akhir.
\end{abstract}

Keywords: Learning Materials, Learning Methods and Hadith 


\section{A. Pendahuluan}

Dunia pendidikan merupakan wadah interaksi dalam mengembangkan potensi yang dimiliki siswa. Proses interaksi dalam proses belajar-mengajar tersebut erat kaitannya dengan transfer of knowledge (mentransfer pengetahuan dan pengalaman) dan juga transfer of value (mentransfer nilai-nilai moral dan kebaikan). Dalam konteks ilmu pendidikan, ada dua hal yang tidak boleh diabaikan yaitu materi dan metode pembelajaran. Sedangkan dalam konteks pendidikan Islam, materi dan metode pembelajaran tersebut harus merujuk pada nilai-nilai prophetik Nabi Muhammad Saw.

Perjalanan Rasulullah Saw dalam setiap misi mengajarnya tidak lepas dari apa yang akan diajarkan, dan bagaimana beliau mengajarkannya kepada Sahabat. Merujuk pada pola pendidikan dan keguruan Rasulullah Saw, dalam perspektif Islam, guru menjadi posisi kunci dalam membentuk kepribadian muslim yang sejati. Selanjutnya adalah penguasaan materi dan metode pembelajaran yang sesuai dengan nilai-nilai prophetik Nabi Muhammad Saw. Oleh karena itu, memahami konteks pendidikan Islam dengan pendekatan prophetik saat ini sangat menarik untuk dikaji lebih jauh.

Bila dilihat dari sisi kehidupan Rasulullah Saw sebagai murobbi menjadikan beliau harus memiliki seribu satu cara jitu untuk menyampaikan esensi-esensi dari firman Allah Swt dan Sunnahnya, ini merupakan bagian dari ekspansi Islam. Peristiwa dua puluh tiga tahun ini, dimana Islam tersebar secara luas bahkan masih berkembang sampai saat ini. Tentu ada sesuatu dibalik seribu satu cara Rasulullah Saw. Kajian tentang cara-cara ini tidak banyak yang mengkajinya oleh tokoh-tokoh klasik, hadishadis itu lebih banyak masuk kepada sub bab tentang esensi dari matan hadis itu. Namun hadis-hadis Rasulullah Saw tidak sedikit yang berbicara soal proses pembelajaran bila kita lihat dari sisi pendidikan. Rasul sendiri juga memiliki tempat mengajar, yaitu di timur masjid Nabawi, di Raudhoh, bersandar ke dinding kamar Sayyidah 'Aisyah ra. ${ }^{1}$ Ditempat itulah biasanya Rasulullah Saw diwaktu dhuha setelah sholat mengajarkan ilmu kepada sahabatnya.

\footnotetext{
${ }^{1}$ Naufal bin Muhammad al-'Aidarus, Sehari Bersama Rasul: 24 Jam Aktivitas Baginda Muhammad (Surakarta: Taman Ilmu, 2015), 52.
} 
Salah satu hadis yang dikaji ini juga terjadi disaat Rasulullah Saw sedang berkumpul bersama para sahabatnya dalam majlis ilmu. Hadist yang diriwayatkan oleh Muslim no. 8 kebanyakan ulama memasukannya dalam sub bab yang berkaitan dengan matan hadis ini, yaitu Iman, Islam, Ihsan dan Hari Akhir. Namun, kali ini akan melihat dari sisi lain: bagaimana cara Rasulullah Saw menyampaikan pesan ilmu?

\section{B. Pembahasan}

Berikut adalah hadist shahih yang diriwayatkan Imam Muslim:

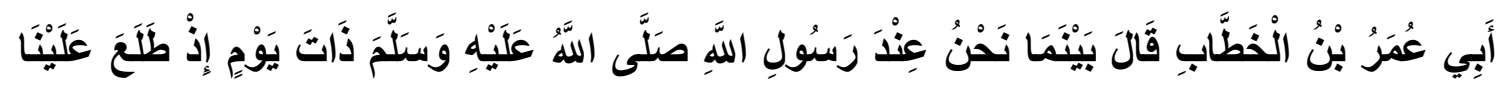

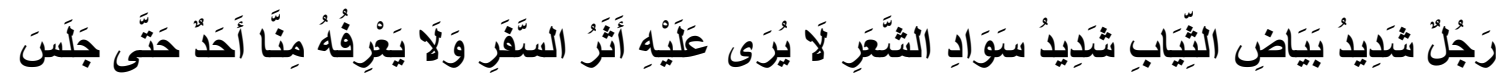

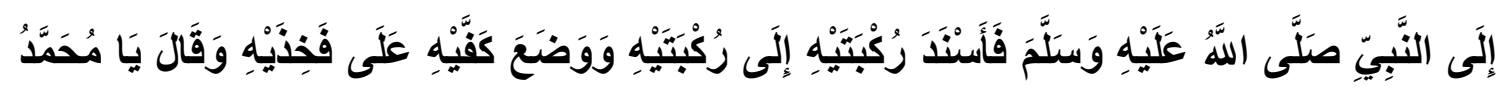

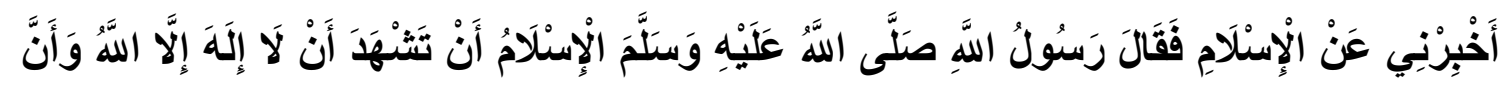

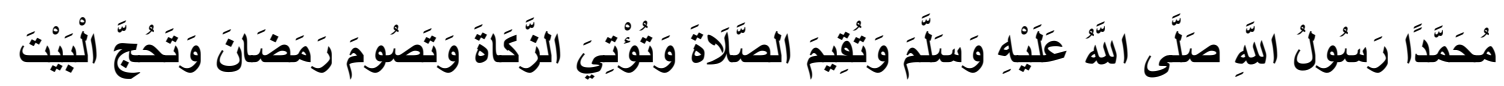

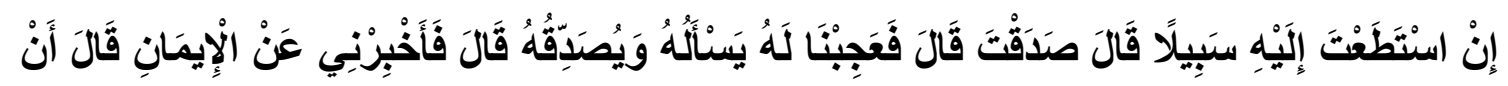

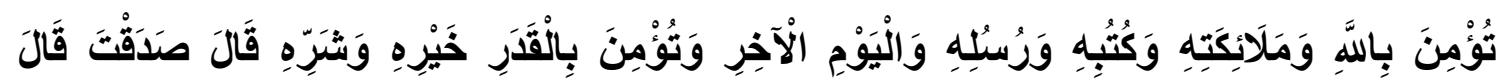

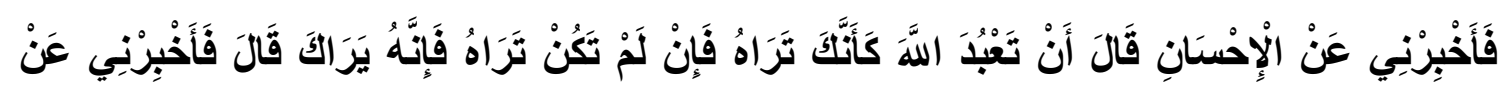

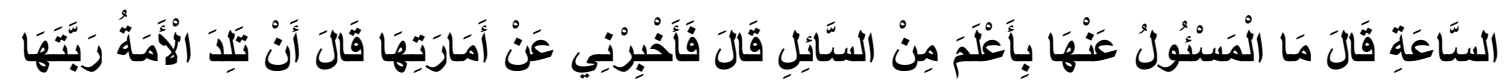

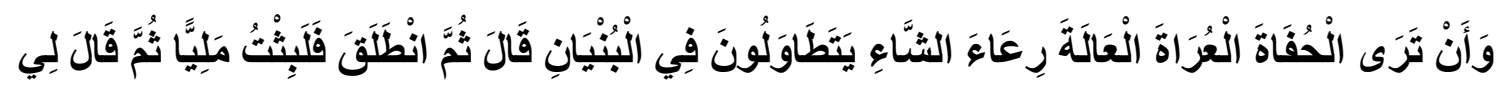

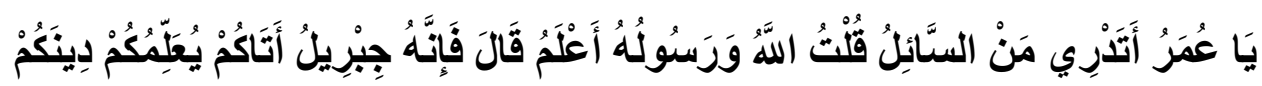

Artinya:

Umar bin al-Khaththab berkata, "Dahulu kami pernah berada di sisi Rasulullah shallallahu 'alaihi wasallam, lalu datanglah seorang laki-laki yang bajunya sangat putih, rambutnya sangat hitam, tidak tampak padanya bekas-bekas perjalanan. Tidak seorang pun dari kami mengenalnya, hingga dia mendatangi Nabi Shallallahu 'Alaihi Wasalam lalu menyandarkan lututnya pada lutut Nabi Shallallahu 'Alaihi Wasalam", kemudian ia berkata, "Wahai Muhammad, kabarkanlah kepadaku tentang Islam?" Rasulullah Shallallahu 'Alaihi Wasalam menjawab: "Kesaksian bahwa tidak ada tuhan (yang berhak disembah) selain Allah dan bahwa Muhammad adalah hamba dan utusan-Nya, 
mendirikan shalat, menunaikan zakat, dan puasa Ramadlan, serta haji ke Baitullah jika kamu mampu bepergian kepadanya.” Dia berkata, "Kamu benar.” Umar berkata, "Maka kami kaget terhadapnya karena dia menanyakannya dan membenarkannya." Dia bertanya lagi, "Kabarkanlah kepadaku tentang iman itu?" Beliau menjawab: "Kamu beriman kepada Allah, malaikat-malaikat-Nya, kitab-kitab-Nya, para Rasul-Nya, hari akhir, dan takdir baik dan buruk." Dia berkata, "Kamu benar." Dia bertanya, "Kabarkanlah kepadaku tentang ihsan itu?" Beliau menjawab: "Kamu menyembah Allah seakan-akan kamu melihat-Nya, maka jika kamu tidak melihat-Nya, maka sesungguhnya Dia melihatmu." Dia bertanya lagi, "Kapankah hari akhir itu?” Beliau menjawab: "Tidaklah orang yang ditanya itu lebih mengetahui daripada orang yang bertanya." Dia bertanya, "Lalu kabarkanlah kepadaku tentang tanda-tandanya?" Beliau menjawab: "Apabila seorang budak melahirkan (anak) tuan-Nya, dan kamu melihat orang yang tidak beralas kaki, telanjang, miskin, penggembala kambing, namun bermegah-megahan dalam membangun bangunan." Kemudian dia bertolak pergi. Maka aku tetap saja heran kemudian beliau berkata; "Wahai Umar, apakah kamu tahu siapa penanya tersebut?” Aku menjawab, “Allah dan Rasul-Nya lebih tahu.” Beliau bersabda: "Itulah Jibril, dia mendatangi kalian untuk mengajarkan kepada kalian tentang pengetahuan agama kalian. (H.R. Muslim). ${ }^{2}$

Beberapa pandangan ulama terkait hadist di atas, Qadhi 'Iyaadh: "Hadis ini mampu mewakili penjelasan mengenai segala unsur ibadah, baik yang bersifat lahir maupun batin. Hadis ini juga mencakup penjelasan mengenai iman, aktifitas fisik, keikhlasan batin, dan pemeliharaan diri dari unsur-umsur yang bisa merusak nilai ibadah". ${ }^{3}$ Imam Nawawi: "Hadis ini menghimpun berbagai macam ilmu, pengetahuan, dan ajaran tentang nilai-nilai etis. Bahkan hadis tersebut, merupakan hadis inti tentang Islam. Seperti yang diriwayatkan dari Qodhi 'Iyaadh". ${ }^{4}$ Ibnu Daqiqil al 'Id: "Hadis ini seakan menjadi induk bagi sunnah, sebagaimana al-Fatihah dinamakan Ummul Qur'an, karena ia mencakup seluruh nilai-nilai yang ada dalam al-Qur'an.”

\footnotetext{
${ }^{2}$ Imam an-Nawawi, Syarah Shahih Muslim, Terj. Wawan Djunaedi (Jakarta: Pustaka Azzam, 2010), 358-59.

${ }^{3}$ Ibid., 396.

${ }^{4} \mathrm{Ibid}, . .$, hlm. 400
} 
Kelengkapan hadis ini, menjadikan beberapa ulama di atas berpendapat bahwa percakapan antara malaikat Jibril dan Rasulullah Saw ialah untuk mengajarkan kepada para sahabat dan umumnya kepada umat nabi Muhammad Saw tentang rukun agama, yaitu iman, Islam, ihsan, dan hari akhir. ${ }^{5}$

1. Cara Rasulullah Saw Menyampaikan Ilmu

Sebelum kita membahas lebih dalam mengenai metode apa yang Rasulullah Saw gunakan dalam redaksi hadist tersebut, kita mulai dari hakikat metode. Metode secara etimologi, istilah metode berasal dari bahasa Yunani "Motodos". Kata ini terdiri dari dua suku kata, yaitu "Metha" yang berarti melewati atau melalui dan "Hodos" yang berarti berjalan atau cara ${ }^{6}$ Seacara makna teori, metode merupakan caranya dalam menyampaikan suatu materi, baik materi yang bersifat nyata maupun yang bersifat ghoib. Metode menjadi sangat penting bilamana materi yang ingin disampaikan dapat diterima atau dipahami secara maksimal.

Bukan hanya soal penting atau tidaknya, melainkan ketetapan penggunaan metode juga berpengaruh signifikan dalam ketercapaian suatu tujuan. Dalam dunia pendidikan khususnya di sekolah formal, metode digunakan dalam proses belajar mengajar, agar tujuan utama dari pendidikan itu dapat tercapai. Maka dari itu, guru atau pendidik harus memiliki suatu cara atau metode yang unik, menarik, dan menyenangkan dalam menyampaikan materi kepada siswa, dengan model yang unik, menarik dan menyenangkan maka materi yang disampaikan kepada siswa akan mudah diterima dan dicerna oleh siswa itu sendiri. ${ }^{7}$ Tetapi dalam pemilihannya perlu pertimbangan untuk menentukan suatu metode yang tepat guna, beberapa diantaranya menurut penulis ialah jenis materi yang disampaikann kebudayaan penerima (siswa), dan waktu penyampaian. ${ }^{8}$ Namun pada prinsipnya, bila bercermin pada hadist Nabi SAW yang

5 Ibnu Daqiqil al 'Ied, Syarah Arba'in Nawawi: Penjelasan 40 Hadist Inti Ajaran Islam (Yogyakarta: : Hikam Pustaka, n.d.), 19.

${ }^{6}$ Armai Arief, Pengantar Ilmu Dan Metodologi Pendidikan Islam (Jakarta: Ciputat Pers, 2002), 40.

${ }^{7}$ Teni Nurrita, "Pengembangan Media Pembelajaran untuk Meningkatkan Hasil Belajar Siswa," MISYKAT: Jurnal Ilmu-ilmu Al-Quran, Hadist, Syari'ah dan Tarbiyah 3, no. 1 (June 27, 2018): 176-78, doi:10.33511/misykat.v3n1.171.

${ }^{8}$ H M Sjaroni et al., "Jurnal Studi Pendidikan Islami” 02, no. 01 (2016): 62-65. 
diriwayatkan oleh Bukhori: "Mudahkanlah dan janganlah kamu mempersulit. Gembirakanlah dan janganlah kamu membuat mereka lari” (H.R. Bukhori).

Merujuk kepada hadist kedatangan malaikat jibril untuk menemui Rasulullah Saw, bila kita telaah lebih dalam terdapat tiga subjek yang berperan dalam redaksi hadist tersebut. Ketiga redaksi tersebut ialah malaikat Jibril, Rasulullah SAW, dan sahabat Umar bin Khattab. Malaikat Jibril dalam peristiwa ini menampakkan wujudnya dalam bentuk manusia. Hal tersebut yang juga menjadikan Jibril bergelar Syadidul Quwa, yang ditafsiri sebagai sosok yang gagah dengan wujud manusia biasa. ${ }^{9}$ Sebagaimana redaksi hadist berikut: "Di suatu hari tiba-tiba ada seseorang yang pakaiannya sangat putih dan rambutnya sangat hitam, tiba-tiba muncul. Ia tidak terlihat tanda-tanda perjalanannya dan tak seorang pun dari kami mengenalnya."

Penjelasan yang ditunjukan malaikat Jibril dalam wujud manusaia, ialah memberikan kontribusi dalam kelancaran misi Rasulullah Saw dalam penyampaian Ilmu (Trasfer Knowledge). Redaksi ilmu akan dapat dicerna atau terima lebih mudah oleh sahabat, dari pada Jibril tidak menampakkan wujudnya sebagai manusia biasa. Percakapan yang terjadi antara malaikat Jibril dalam wujud manusia dengan Rasulullah Saw merupakan esensi dari materi yang diajarkan kepada para sahabatnya. Dalam dunia pendidikan, peristiwa seperti apa yang ada dalam hadist tersebut ialah percakapan Jibril dengan Rasulullah Saw, yang dikenal dengan metode tanya jawab atau dialog. ${ }^{10}$

Metode tanya jawab ialah cara penyajian pelajaran dalam bentuk pertanyaan yang harus dijawab, terutama dari guru kepada murid atau dapat juga dari murid kepada guru. ${ }^{11}$ Setelah Jibril pergi atau meninggalkan Rasulullah Saw, Rasulullah Saw juga bertanya kepada sahabatnya, namun esensi dari pertanyaan ini hanya sebagai pelengkap dialog antara Rasulullah Saw dengan Malaikat Jibril. "Kemudian Rasul berkata kepadaku: Wahai Umar, kamu tahu orang yang bertanya tadi? Aku menjawab: “Allah

\footnotetext{
${ }^{9}$ Quraish Syihab, Yang Tersembunyi: Jin, Iblis, Setan Dan Malikat Dalam al-Qur'an - asSunnah Serta Wacana Pemikiran Ulama Masa Lalu Dan Masa Kini, (Lentera Hati, n.d.), 87.

${ }^{10}$ Ahmad Muntakhib, "Urgensi Nilai-Nilai Pendidikan Karakter dalam Kitab Al-Arba'̄̄n AlNawawiyyah bagi Perkembangan Kualitas Pendidikan Indonesia” 2, no. 1 (2017): 43-47.

${ }_{11}$ Bukhori Umar, Hadist Tarbawi: Pendidikan Dalam Perspektif Hadist, (Jakarta: Azmah, 2016), 128.
} 
dan Rasulnya yang lebih tahu." Rasul berkata: "Sesungguhnya orang itu adalah Jibril yang mendatangi kalian untuk mengajarkan agama kalian." 12 Dalam hadis ini dinyatakan bahwa Jibril datang mengajarkan agama kepada sahabat Nabi, berikut redaksi hadisnya:

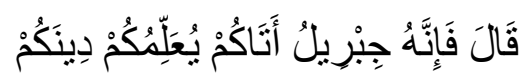

Artinya: "Rasul berkata: sesungguhnya orang itu adalah Jibril yang mendatangi kalian untuk mengajarkan agama Islam”.

Bila dipahami lebih mendalam arti dalam proses di atas, ialah malaikat Jibril berfungsi sebagai guru (Mualim), sedangkan Rasulullah Saw sebagai narasumber, dan para sahabat sebagai peserta didik atau siswa. Penggunaan metode tanya jawab ditunjukan guna menarik minat dan memusatkan perhatian para sahabatnya untuk dapat memiliki rasa ingin tahu lebih mendalam. ${ }^{13}$

2. Esensi Pesan Rasulullah Saw.

Materi pendidikan menjadi hal yang penting disamping penggunaan metode. Karena tanpa pemilihan materi yang sesuai berarti tidak ada pula pesan yang akan disampaikan. Selain itu, dalam konteks kekinian materi dan metode tersebut dapat disampaikan dengan menggunakan beragam perangkat media. ${ }^{14}$ Mayoritas sistem pendidikan di Indonesia, di lembaga pendidikan SD, SMP, SMA dan setingkatnya, materi pembelajaran yang akan di berikan atau disampaikan oleh guru sudah masuk atau berbentuk silabus dan rencana pelaksanaan pembelajaran (RPP). Di dalamnya tersebut terdapat beberapa unsur, yaitu unsur ilmu agama dan ilmu umum. Perbedaan ini tidak menjadi persoalan, namun saling bersinegi. Materi ilmu agama dimaksudkan al-Qur'an, Hadist, Fiqih, Akhlak, Sejarah Islam (Tarikh Islam), dan Bahasa Arab ${ }^{15}$.

12 Syahrizal Afandi, "Kajian Hadits Jibril dalam Perspektif Pendidikan (Kajian Materi Pembelajaran dan Metode Pembelajaran)," JURNAL PENELITIAN KEISLAMAN 15, no. 1 (November 25, 2019): 37, doi:10.20414/jpk.v15i1.525.

${ }^{13}$ Susan Noor Farida, "Hadis-Hadis tentang Pendidikan," 2016, 37-40.

${ }^{14}$ Ari Wibowo, "Komodifikasi Agama: Studi Analisis Terhadap Tampilan Agama Di Media Televisi," Edugama: Jurnal Kependidikan dan Sosial Keagamaan (2020).

${ }^{15}$ Abdul Majid Khon, Hadist Tarbawi: Hadist-Hadist Pendidikan (Jakarta: Kencana, 2014), 105. 
Menurut Nasih, mata pelajaran Pendidikan Agama Islam secara keseluruhan terbagi dalam empat cakupan, yaitu al-Qur'an dan Hadist, Keimanan, Akhlak, dan Fiqih Ibadah $^{16}$. Empat cakupan tersebut setidaknya menggambarkan bahwa ruang lingkup PAI diaharapkan dapat mewujudkan kesearasian, keselarasan dan keseimbangan hubungan manusia dengan Allah Swt, diri sendiri, sesame manusia, makhluk lainnya maupun lingkungannya. ${ }^{17}$

Berkaitan dengan klasifikasi materi hadis, sejatinya semua yang disampaikan Rasulullah Saw merupakan materi-materi pendidikan. ${ }^{18}$ karena ketika Rasul menyampaikan suatu ilmu kepada sahabatnya, sejatinya itulah proses pendidikan ala Rasulullah Saw. ${ }^{19}$ Jika kita berkiblat pada undang-undang yang mengatakan bahwa pendidikan adalah usaha sadar dan terencana untuk mewujudkan suasana belajar dan proses pembelajaran agar peserta didik secara aktif mengembangkan potensi dirinya untuk memiliki kekuatan spiritual keagamaan, pengendalian diri, kepribadian, kecerdasan, akhlak mulia, serta keterampilan yang diperlukan dirinya, masyarakat, bangsa dan Negara. ${ }^{20}$ Maka hampir semua yang dilakukan Rasulullah Saw adalah pendidikan itu sendiri. Kemudian, dengan apa yang dideskripsikan ini menjadi esensi dari dialog dalam hadis tersebut dalam tinjauan materi:

a. Definisi Islam

Malaikat Jibril bertanya kepada Nabi Muhammad Saw mengenai Islam, kemudian beliau menjawab:

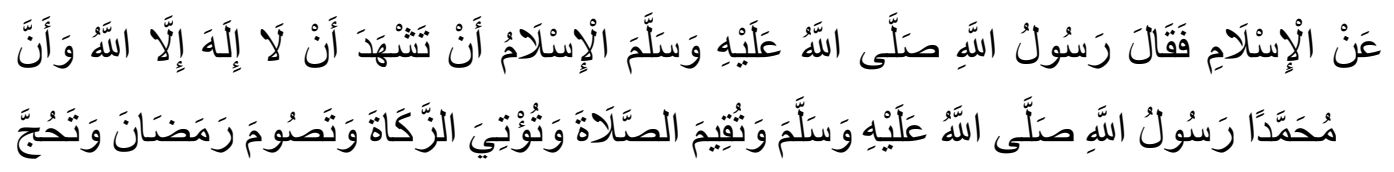

${ }^{16}$ Universitas Islam Negeri Alauddin Makassar and Munirah Munirah, "Pendidikan Islam dalam Perspektif Hadis," Lentera Pendidikan : Jurnal Ilmu Tarbiyah dan Keguruan 19, no. 2 (December 15, 2016): 217-19, doi:10.24252/lp.2016v19n2a7.

17 A M Nasih dan L.N Kholidah, Metode Dan Teknik Pembelajaran Pendidikan Agama Islam (Bandung: Refika Aditama, 2009), 47.

${ }_{18}$ M Hatta, "Implementasi Isi atau Materi Pendidikan (Iman, Islam, Ihsan, Amal Saleh, Dan Islah) Di SD Muhammadiyah 7 Pekanbaru” 2, no. 1 (2019): 15.

19 Robiatul Awwaliyah and Hasan Baharun, "Pendidikan Islam dalam Sistem Pendidikan Nasional (Telaah Epistemologi terhadap Problematika Pendidikan Islam)” 19, no. 1 (2018): 94-95.

${ }^{20}$ Undang-Undang No. 20 Tahun 2003, Tentang Sistem Pendidikan Nasional, Bab I, Pasal 1., n.d. 


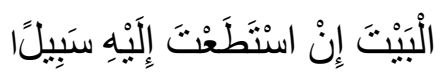

Artinya: "Islam adalah, engkau bersaksi tiada ada yang berhak diibadahi dengan benar melainkan hanya Allah, dan sesungguhnya Muhammad adalah Rasul Allah: menegakkan shalat; menunaikan zakat; berpuasa di bulan Ramadhan, dan engkau menunaikan haji ke Baitullah, jika engkau mampu melakukannya". Rasulullah Saw menjelaskan tentang rukun dalam Islam, dimana mencakup tentang akidah dan syariah (fiqih). Dimana agama adalah fikih, karena mencakup segala perbuatan manusia dalam kehidupannya setelah dia beriman. Jika dilihat dari segi urgensi hukum memang sangan urgen, Karena agama memang berisikan hukum. ${ }^{21}$ Karena dalam rukun Isalam, setelah dia bersyahadat (beriman), barulah dia berkena pasalpasal berikutnya, yaitu kewajiban shalat, zakat, puasa ramadhan dan pergi haji bila mampu. ${ }^{22}$ Seseorang belum dikatakan beragama Islam dengan sempurna jika belum melakukan lima perkara secara keseluruhan. ${ }^{23}$ Kecuali jika disyaratkan adanya kemampuan seperti zakat dan haji. Karenanya, tidaklah mungkin bila materi pendidikan agama Islam tidak mengajarkan materi Islam itu sendiri sebagai dasarnya.

\section{b. Definisi Iman}

Iman menurut bahasa berarti kepercayaan, keyakinan, ketetapan hati, atau keteguhan hati. ${ }^{24}$ Materi terkait keimanan terdapat dalam mata pelajaran aqidah di madrasahmadrasah. Tujuannya ialah memperkokoh keimanan siswa pada tiap jenjang belajarnya. Redaksi hadist tersebut tentang iman dijelaskan Rasulullah Saw sebagai berikut: "Iman itu adalah kamu meyakini (iman) kepada Allah, para malaikat-Nya, kitab-kitab-Nya, para rasul-Nya, hari akhir, dan mengimani qadha dan qadar yang baik ataupun yang tidak baik". ${ }^{25}$ Secara konsep memang seperti demikian yang

\footnotetext{
${ }^{21}$ Abdul Majid Khon, Hadist Trbawi: Hadist-hadist,..., h. 23

${ }^{22}$ Misbahuddin Jamal, “Konsep Al-Islam dalam Al-Qur'an,” n.d., 286.

${ }^{23}$ Rusdiana Navlia Khulaisie, "Hakikat Kepribadian Muslim, Seri Pemahaman Jiwa terhadap Konsep Insan Kamil” 11, no. 11 (2016): 42.

${ }^{24}$ WJS. Poerdarwinta, Kamus Bahasa Indonesia, (Jakarta: Balai Pustaka, n.d.), 18.

25 Jarnawi Muhammad Nur, Azhari Azhari, and Adzanmi Urka, "Implementasi Prinsip Yakin pada Rukun Iman dalam Konseling Islam," Irsyad: Jurnal Bimbingan, Penyuluhan, Konseling, dan Psikoterapi Islam 8, no. 3 (September 30, 2020): 256-57, doi:10.15575/irsyad.v8i3.2049.
} 
disampaikan Rasulullah Saw, namun terdapat hadist lain yang mengatakan bahwa: "Iman adalah pengakuan dengan hati, pengucapan melalui lidah, dan pengenalan dengan anggota badan". (H.R. Ibnu Majah). ${ }^{26}$ Sebagai gambaran perbedaan antara Iman dan Islam, Khon mengatakan bahwa Iman adalah membenarkan dasar-dasar Islam sedangkan Islam adalah kepatuhan perbuatan lahir secara syara'. Keduanya memang berbeda, tetapi selalu bersama dan saling melazimi. ${ }^{27}$ Terdapat hal yang menarik dari hadist kedatangan Jibril, bahwa ketika Rasulullah Saw menyampaikan konsep tentang iman, beliau mengulang kata iman dalam penjelasan konsepnya. ${ }^{28}$ Padahal dalan ilmu membuat konsep pengertiab yang baik, ${ }^{29}$ ialah tidak menngulang kata yang digunakan untuk menjelaskannya. Maka muncullah hipotesa bahwa yang menerima ilmu itu sudah mengerti tentang maksud dari "iman"itu. ${ }^{30}$

c. Definisi Ihsan

Rasulullah Saw bersabda dalam hadist diatas berkaitan dengan ihsan, bahwa: "Rasul menjawab: ihsan adalah jika kamu beribadah kepada Allah seolah-olah kamu melihat-Nya, jikalau kamu tidak melihat-Nya, sesungguhnya Dia melihatmu.” Ihsan yang disebutkan dalam hadis adalah dalam ibadah. Adapun ihsan diluar ibadah, maknanya kita bawa makanan ihsan tersebut dalam segala kehidupan kita, dimana saja dan kapan saja kita selalu ingat diawasi oleh Allah Swt. ${ }^{31}$ Materi pendidikan pun seyogyanya mengajarkan tentang ihsan ini, baik dalam hal ibadah maupun dalam kegiatan-kegiatan diluar ibadah. Sikap ihsan yang kita harapkan, sebenarnya kembali lagi ke redaksi yang menjadi dasar, yaitu terkait imanan. Dalam ajaran Islam, kejujuran juga dituntut kepada orang yang berilmu apabila ditanya tentang ilmu

\footnotetext{
${ }^{26}$ Afandi, "Kajian Hadits Jibril dalam Perspektif Pendidikan (Kajian Materi Pembelajaran dan Metode Pembelajaran)," 33.

${ }^{27}$ Hadist Tarbawi: Hadist-Hadist Pendidikan, 51.

${ }^{28}$ Shodiq Shodiq, "Pengukuran Keimanan: Perspektif Psikologi," Nadwa 8, no. 1 (April 19, 2014): 127-28, doi:10.21580/nw.2014.8.1.573.

${ }^{29}$ M Hatta, "Implementasi Isi atau Materi Pendidikan (Iman, Islam, Ihsan, Amal Saleh, Dan Islah) Di SD Muhammadiyah 7 Pekanbaru” 2, no. 1 (2019): 18.

${ }^{30}$ Nurul Huda, "Konsepsi Iman Menurut al-Baiḍāwi dalam Tafsir Anwār at-Tanz ${ }^{-}$il wa Asra ${ }^{-} \mathrm{r}$ at-Ta'wi- 1," Analisa 20, no. 1 (June 30, 2013): 71-72, doi:10.18784/analisa.v20i1.6.

${ }^{31}$ Ibid., 10.
} 
pengetahuan ia wajib menjawab sebat kemampuannya, bila tidak, maka Allah mengancamnya dengan siksa yang amat pedih.

\section{Adab dalam Majelis Ilmu}

Rasulullah Saw bersabda dalam hadistnya: "Di suatu hari tiba-tiba ada seseorangan yang pakaiannya sangat putih dan rambutnya sangat hitam, tiba-tiba muncul". ${ }^{32}$ Adab berpakaian yang sopan dan rapih ketika mendatangi majelis ilmu mencoba di deskripsikan dalam hadist. sosok Jibril yang menjelma menjadi manusia biasa, digambarkan bahwa tidak ada seorang sahabat pun yang mengetahui kedatangannya. Kebudayaan orang Arab waktu itu, jika seseorang melakukan perjalanan jauh, maka akan terlihat bekas perjalanannya seperti rambut yang berantakan dan berdebu. Namun tidak halnya dengan Jibril, dengan kekuatannya dia berpenampilan rapih dan sopan. ${ }^{33}$ "Dia duduk menuju Nabi Saw menyandarkan kedua lututnya pada kedua lutut Nabi, seraya meletakan kedua telapaknya diatas dua paha Nabi”. Sikap duduk yang diajarkan dalam hadist mengajarkan adab duduk dalam majlis ilmu. Memangan konteks dahulu dengan sekarang berbeda. Namun esensi kesopanan dalam duduk masih tetap relevan dengan zaman sekarang.

\section{Penutup}

Mempelajari sejarah kehidupan Rasulullah Saw, akan sangat menarik, karena banyak sisi-sisi beliau yang berbau atau bernilai pendidikan. Peran beliau dalam mengIslamkan para kaum juga merubah perilaku buruk merka, adalah salah satu tugas yang sangat diapresiasi. Perjalanan waktu yang telah membuktikan kehebatan beliau dalam mengepakkan sayap-sayap perjuangan. Banyak startegi-strategi pengajaran beliau yang ternyata itu merupakan dasar dalam pelaksanaan pendidikan saat ini. Wajar bilamana perkembangan materi dan metode pendidikan itu terus ada, karena manusia dan dunia juga tidak statis. Sedikit dari sekian banyak cara beliau dalam menyampaikan pemahaman ilmu kepada para sahabatnya, tetuang dala hadist yag telah dikaji diatas.

\footnotetext{
${ }^{32}$ Fahmi Sahlan, "Analisis Kajian Hadits Tentang Metodologi Pembelajaran Rasulullah SAW," Almarhalah | Jurnal Pendidikan Islam 4, no. 2 (September 30, 2020): 100, doi:10.38153/alm.v4i2.39.

${ }^{33}$ Afandi, "Kajian Hadits Jibril dalam Perspektif Pendidikan (Kajian Materi Pembelajaran dan Metode Pembelajaran)," 30.
} 
Pelajaran berharga yang dapat diambil dari hadist tersebut ialah tidak semua orang yang bertanya itu tidak mengetahuinya. Sikap kepedulian, menjadikan seseorang mau menananyakan untuk orang lain. sikap kejujuran dalam berilmu ditunjukkan pula oleh sahabt Umar bin Khattob beliaubertnya oleh Nabi terkait Jibril. Maslah adab menjadi pekerjaan besar bangsa ini hingga muncul degradasi moral anak sekolah. Tentu sangat perlu untuk bercermin kembalu kepada hadist Nabi tersebut.

\section{Daftar Pustaka}

A M Nasih dan L.N Kholidah. Metode Dan Teknik Pembelajaran Pendidikan Agama Islam. Bandung: Refika Aditama, 2009.

Abdul Majid Khon. Hadist Tarbawi: Hadist-Hadist Pendidikan. Jakarta: Kencana, 2014.

Afandi, Syahrizal. "Kajian Hadits Jibril dalam Perspektif Pendidikan (Kajian Materi Pembelajaran dan Metode Pembelajaran)." JURNAL PENELITIAN KEISLAMAN 15, no. 1 (November 25, 2019): 29-42. doi:10.20414/jpk.v15i1.525.

Armai Arief. Pengantar Ilmu Dan Metodologi Pendidikan Islam. Jakarta: Ciputat Pers, 2002.

Awwaliyah, Robiatul, and Hasan Baharun. "Pendidikan Islam dalam Sistem Pendidikan Nasional (Telaah Epistemologi terhadap Problematika Pendidikan Islam)” 19, no. 1 (2018): 16.

Bukhori Umar. Hadist Tarbawi: Pendidikan Dalam Perspektif Hadist,. Jakarta: Azmah, 2016.

Farida, Susan Noor. "Hadis-Hadis tentang Pendidikan," 2016, 8.

Hatta, M. "Implementasi Isi atau Materi Pendidikan (Iman, Islam, Ihsan, Amal Saleh, Dan Islah) Di SD Muhammadiyah 7 Pekanbaru" 2, no. 1 (2019): 14.

Huda, Nurul. "Konsepsi Iman Menurut al-Baiḍāwi dalam Tafsir Anwār at-Tanz ${ }^{-}$il wa Asra $^{-} \mathrm{r}$ at-Ta'wi ${ }^{-}$1." Analisa 20, no. 1 (June 30, 2013): 65. doi:10.18784/analisa.v20i1.6.

Ibnu Daqiqil al 'Ied,. Syarah Arba'in Nawawi: Penjelasan 40 Hadist Inti Ajaran Islam. Yogyakarta: : Hikam Pustaka, n.d.

Imam an-Nawawi. Syarah Shahih Muslim, Terj. Wawan Djunaedi. Jakarta: Pustaka Azzam, 2010.

Indrawan, Irjus. "Model Pembelajaran Nabi Muhammad SAW (Hiwar , Analogi , Tashbih, dan Amtsal)." Al-Afkar: Jurnal Keislaman \& Peradaban 1, no. 2 (December 27, 2016). doi:10.28944/afkar.v1i2.43.

Jamal, Misbahuddin. “Konsep Al-Islam dalam Al-Qur'an,” n.d., 28.

Khulaisie, Rusdiana Navlia. "Hakikat Kepribadian Muslim, Seri Pemahaman Jiwa Terhadap Konsep Insan Kamil” 11, no. 11 (2016): 19. 
Muntakhib, Ahmad. "Urgensi Nilai-Nilai Pendidikan Karakter dalam Kitab Al-Arba'īn Al-Nawawiyyah bagi Perkembangan Kualitas Pendidikan Indonesia" 2, no. 1 (2017): 24.

Naufal bin Muhammad al-'Aidarus. Sehari Bersama Rasul: 24 Jam Aktivitas Baginda Muhammad. Surakarta: Taman Ilmu, 2015.

Nur, Jarnawi Muhammad, Azhari Azhari, and Adzanmi Urka. "Implementasi Prinsip Yakin pada Rukun Iman dalam Konseling Islam." Irsyad: Jurnal Bimbingan, Penyuluhan, Konseling, dan Psikoterapi Islam 8, no. 3 (September 30, 2020): 255-70. doi:10.15575/irsyad.v8i3.2049.

Nurrita, Teni. "Pengembangan Media Pembelajaran untuk Meningkatkan Hasil Belajar Siswa." MISYKAT: Jurnal Ilmu-ilmu Al-Quran, Hadist, Syari'ah dan Tarbiyah 3, no. 1 (June 27, 2018): 171. doi:10.33511/misykat.v3n1.171.

Quraish Syihab. Yang Tersembunyi: Jin, Iblis, Setan Dan Malikat Dalam al-Qur'an as-Sunnah Serta Wacana Pemikiran Ulama Masa Lalu Dan Masa Kini,. Lentera Hati, n.d.

Sahlan, Fahmi. "Analisis Kajian Hadits Tentang Metodologi Pembelajaran Rasulullah SAW." Almarhalah | Jurnal Pendidikan Islam 4, no. 2 (September 30, 2020): 97-106. doi:10.38153/alm.v4i2.39.

Shodiq, Shodiq. "Pengukuran Keimanan: Perspektif Psikologi." Nadwa 8, no. 1 (April 19, 2014): 126. doi:10.21580/nw.2014.8.1.573.

Sjaroni, H M, Abu Amar Bustomi, Helda Nur Ania, Alfan Arifuddin, and H Mat Saifi. "Jurnal Studi Pendidikan Islami" 02, no. 01 (2016): 79.

Undang-Undang No. 20 Tahun 2003, Tentang Sistem Pendidikan Nasional, Bab I, Pasal 1., n.d.

Universitas Islam Negeri Alauddin Makassar, and Munirah Munirah. "Pendidikan Islam dalam Perspektif Hadis." Lentera Pendidikan: Jurnal Ilmu Tarbiyah dan Keguruan 19, no. 2 (December 15, 2016): 209-22. doi:10.24252/lp.2016v19n2a7.

Wibowo, Ari. "Komodifikasi Agama: Studi Analisis Terhadap Tampilan Agama Di Media Televisi." Edugama: Jurnal Kependidikan dan Sosial Keagamaan (2020).

WJS. Poerdarwinta. Kamus Bahasa Indonesia,. Jakarta: Balai Pustaka, n.d. 